\title{
Evaluation of Drip Fertigation in Banana in Kugulur Distributary of LBP Canal Command Area
}

\author{
J. Bhuvaneswari ${ }^{1}$, G. Thiyagarajan ${ }^{2 *}$, M. Manikandan ${ }^{3}$, S. K. Natarajan ${ }^{4}$ \\ and $\mathrm{S}$. Thenmozhi ${ }^{5}$
}

${ }^{1}$ Agricultural College and Research Institute, Tamil Nadu Agricultural University, Killikulam - 628 252, India

${ }^{2}$ Water Technology Centre, Tamil Nadu Agricultural University, Coimbatore - 641 003, India

${ }^{3}$ Agricultural Engineering College and Research Institute, Tamil Nadu Agricultural

University, Kumulur - 621 712, India

${ }^{4}$ Department of Agronomy, Tamil Nadu Agricultural University, Coimbatore - 641 003, India

${ }^{5}$ Agricultural College and Research Institute, Tamil Nadu Agricultural University,

Kudumiyanmalai- 622 104, India

*Corresponding author

\section{A B S T R A C T}

\begin{tabular}{|l|}
\hline Ke y w o r d s \\
Banana, drip \\
fertigation, yield, \\
water use \\
efficiency, \\
economics
\end{tabular}

\begin{abstract}
To evaluate drip fertigation in banana at farmers holdings, On Farm Experiment under Operational Research Project on improved water management technologies in Banana were conducted in farmers fields one each at head, middle and tail reaches of Kugalur distributory of Lower Bhavani Project canal command areas during 2016 and 2017. The experiment consisted of improved water management technology (drip irrigation once in 3 days, application of entire $\mathrm{P}\left(35 \mathrm{~g}_{\text {plant }}{ }^{-1}\right)$ at $3^{\text {rd }}$ month through band placement, fertigation of $\mathrm{N}\left(110 \mathrm{~g} \mathrm{plant}^{-1}\right)$ and $\mathrm{K}\left(330 \mathrm{~g} \mathrm{plant}^{-1}\right)$ in 30 equal splits from $6^{\text {th }}$ week to $35^{\text {th }}$ week after planting and conventional method (1.0 IW/CPE ratio). Drip irrigation laterals were laid with $180 \mathrm{~cm}$ lateral spacing and $0.6 \mathrm{~m}$ lateral spacing and banana were planted with spacing of $1.8 \times 1.8 \mathrm{~m}$ (triangular geometry planting). The discharge rate of the dripper was 4 lph and the irrigation was given once in three days and fertigation of $\mathrm{N}-110 \mathrm{~g} \mathrm{plant}^{-1}$ and $\mathrm{K}-330 \mathrm{~g} \mathrm{plant}^{-1}$ in 30 equal splits was given from $6-35^{\text {th }}$ week after planting. The results of this study revealed that drip fertigation recorded lower water use of $1650 \mathrm{~mm}$ and higher WUE of $12.1 \mathrm{~kg} \mathrm{hamm}^{-1}$ and 26.3 per cent water saving. The higher yield of banana 20.0 tonnes ha $^{-1}$ was recorded in drip fertigation technology which was 26.4 per cent higher than conventional method. The B:C ratio (4.97) was higher in drip fertigation treatment compared to conventional method. Drip irrigation once in 3 days and fertigation of $\mathrm{N}\left(110 \mathrm{~g} \mathrm{plant}^{-1}\right)$ and $\mathrm{K}\left(330 \mathrm{~g} \mathrm{plant}^{-1}\right)$ in 30 equal splits from $6^{\text {th }}$ week to $35^{\text {th }}$ week after planting recorded lower water use, higher WUE, yield and economics in banana.
\end{abstract}

\section{Introduction}

Banana in India is cheap, nutritious and available all round the year. It is an important fruit crop grown in India next to mango. The area under banana was 7.09 lakh hectares in 2008-09 and the production was 26.22 million tonnes in 2008-09 (Anonymous, 2009). It contributes more than $2.8 \%$ to GDP of agriculture in India. Banana requires large quantity of water during its life cycle. In winter, Irrigation is provided at an interval of 7-8 days while in summer it should be given at an interval of 4-5 days (Sharma and 
Kispotta, 2016). However, during rainy season irrigation is provided if required as excess irrigation will lead to root zone congestion due to removal of air from soil pores, thereby affecting plant establishment and growth. In all, about 70-75 irrigations are provided to the crop. The drip method of irrigation also helps in reducing overexploitation of groundwater that partly occurs in surface irrigation. Water saving through drip irrigation system is estimated to be in the range of 12-84 per cent in different crops, besides its beneficial impact on crop yields (Narayanamoorthy, 1997). Among the different irrigation systems, the drip irrigation is reported for its improvement in yield and quality and shorter growing season together with substantial saving in water and energy.

The field experiments were conducted at Agricultural Research Station, Bhavanisagar under AICRP- Irrigation Water Management project resulted better performance of drip fertigation compared to conventional method of irrigation in banana. To test verify that proven technology of drip fertigation in banana, on farm experiments were conducted at farmers holdings in the kugalur distributory of LBP canal area.

\section{Materials and Methods}

On farm experiment under Operational Research Project on improved water management technologies in banana were conducted in farmers fields one each at head, middle and tail reaches of kugalur distributory of Lower Bhavani Project canal command areas during 2016 and 2017 under All India Co-ordinated Project on Irrigation Water Management. The experiment consisted of improved water management technology (drip irrigation 48 litres per plant once in 3 days, application of entire $\mathrm{P}\left(35 \mathrm{~g} \mathrm{plant}^{-1}\right)$ at $3^{\text {rd }}$ month through band placement, fertigation of $\mathrm{N}\left(110 \mathrm{~g} \mathrm{plant}^{-1}\right)$ and $\mathrm{K}$ (330 $\left.\mathrm{g} \mathrm{plant}^{-1}\right)$ in 30 equal splits from $6^{\text {th }}$ week to $35^{\text {th }}$ week after planting) and conventional method (1.0 IW/CPE ratio). The major soil type of the study area was sandy loam in nature and the soil fertility status was low in available nitrogen $\left(235 \mathrm{~kg} \mathrm{ha}^{-1}\right)$, medium in available phosphorus (16 kg ha ${ }^{-1}$ ), and high in potash (309 kg ha ${ }^{-1}$ ). Two methods of Banana cultivation viz., drip fertigation and conventional method were compared by using the variety Kathali. The planting of Banana in the study area was mainly (January February). Drip irrigation laterals were laid with $180 \mathrm{~cm}$ lateral spacing and $0.6 \mathrm{~m}$ lateral spacing and banana were planted with spacing of $1.8 \times 1.8 \mathrm{~m}$ (triangular geometry planting). The discharge rate of the dripper was $4 \mathrm{lph}$ and the irrigation was given once in three days and fertigation of $\mathrm{N}$ (110 g plant $\left.\mathrm{g}^{-1}\right)$ and $\mathrm{K}$ (330 $\left.\mathrm{g} \mathrm{plant}^{-1}\right)$ in 30 equal splits from $6^{\text {th }}$ week to $35^{\text {th }}$ week after planting. For conventional method of cultivation, planting was carried out in ridges and furrows with a spacing of $1.5 \mathrm{~m} \mathrm{x} 1.5 \mathrm{~m}$ and apply $110 \mathrm{~g}$ of $\mathrm{N}$ and $330 \mathrm{~g} \mathrm{plant}^{-1}$ of $\mathrm{K}$ in three equal splits at 3,5 and $7^{\text {th }}$ month. The total water use was calculated by adding irrigation water applied and effective rainfall. The details of test verification in the study area are furnished in Table 1. Banana yield was recorded and total water used, water use efficiency (WUE) and economics were worked out and presented.

\section{Results and Discussion}

\section{Effect of irrigation and fertigation on total water used and water use efficiency}

The water use studies of both the cultivation methods clearly indicated the beneficial effect of drip fertigation in terms of water saving and higher Water Use Efficiency (WUE) (Table 2). The mean total water use under drip fertigation was $1650 \mathrm{~mm}$ which was considerably lesser than conventional method which utilized $2084 \mathrm{~mm}$ water. 
Thus a substantial quantity of water saving by 26.3 per cent was noticed due to the adoption of drip fertigation. The higher cane yield coupled with enormous quantity of water saving under drip fertigation resulted in higher water use efficiency in both the years of experimentation. The results were in accordance with the results of the similar experiment conducted at Agricultural Research Station, Bhavanisagar. The mean WUE of drip fertigation was $12.1 \mathrm{~kg} \mathrm{hamm}^{-1}$ while it was only $7.1 \mathrm{~kg} \mathrm{hamm}{ }^{-1}$ in conventional method of banana cultivation. The increase in WUE under drip fertigation was mainly due to better performance of the crop and improvement in yield by effective utilization of available water and nutrients applied at regular intervals throughout the crop period to meet the crop demand. Pramanik and Patra (2016) reported that higher water use and lower irrigation water use efficiency were observed under the conventional surface irrigation. Pramanik et al., (2014) observed that the irrigation wateruse was found to be highest under the conventional method of irrigation $(57.0 \mathrm{~cm}$ for plant crop and $33.0 \mathrm{~cm}$ for ratoon crop) for the lifecycle of the crop. The irrigation requirement of the crop was found to be lower in plants under drip fertigation. Considerable saving in water $(41.7 \%$ in plant and $40.4 \%$ in ratoon crop) was observed in drip fertigation under 60 per cent CPE and 80 per cent RDF. The water-saving was about 29 per cent in banana due to adoption of drip irrigation over flood irrigation (Narayanamoorthy, 2003).

\section{Effect of drip fertigation on banana yield}

In the present study, yield of banana was substantially increased due to the adoption of drip fertigation (Table 2). Averaging over locations, drip fertigation registered a mean yield of $20.0 \mathrm{t} \mathrm{ha}^{-1}$ which was significantly higher than surface irrigation and normal fertilizer application $\left(14.7 \mathrm{tha}^{-1}\right)$. The average yield increment by drip fertigation was 26.4 per cent over conventional method of cultivation. Higher yield under drip fertigation was mainly due to the availability of sufficient sunlight with better aeration coupled with adequate availability of soil moisture and nutrients throughout the crop growth period.

Thadchayini and Thiruchelvam (2005) reported $31 \%$ higher banana yield in drip irrigation compared to surface irrigation. Sharma and Kispotta (2016) reported that Yield is $21.95 \%$ more. $38.82 \%$ water is being saved by drip system. Hegde and Srinivas (1990) indicated an increase in the banana yield under drip irrigation compared to the basin irrigation. The yield improvement under drip irrigation was mainly due to the maintenance of soil near field capacity throughout the growth period in the active root zone, leading to low soil suction, which thereby facilitated better water utilization, higher nutrients uptake and excellent maintenance of soil-water-air relationship with a higher oxygen concentration in the root zone (Kumar et al., 2008; Raina et al., 2011).

\section{Economics of drip fertigation in sugarcane}

The economic analysis of both the methods of cultivation (Table.2) revealed that though the cost of cultivation was comparatively higher under drip fertigation it was found to be economically better than conventional method of cultivation. Drip fertigation fetched a mean gross income of Rs.7,52,917 $\mathrm{ha}^{-1}$ as against Rs 5,51,250 ha ${ }^{-1}$ under conventional method.

In addition, higher net income and benefit cost ratio were also associated with drip fertigation. Higher net income and Benefit Cost ratio of Rs 6,01,450 ha ${ }^{-1}$ and 4.97 were registered by drip fertigation as compared to Rs 4,13,833 $\mathrm{ha}^{-1}$ and 4.02 respectively under conventionally irrigated and fertilized banana. 
Table.1 Details of ORP on drip fertigation in the kugalur distributory

\begin{tabular}{|l|l|l|}
\hline \multicolumn{1}{|c|}{ Particular } & \multicolumn{1}{|c|}{$\mathbf{2 0 1 6}$} & \multicolumn{1}{c|}{$\mathbf{2 0 1 7}$} \\
\hline Area of demonstration (ha) & \multicolumn{1}{|c|}{3.0} & \multicolumn{1}{c|}{3} \\
\hline No of farmers (Head, middle, tail) & \multicolumn{1}{|c|}{3} & \multicolumn{1}{|c|}{ A.Thangamani } \\
\hline Name of the farmers & $\begin{array}{l}\text { K.S.Ganesan } \\
\text { O.N. Chinnusamy }\end{array}$ & $\begin{array}{l}\text { K.N.Dhanabalan } \\
\text { K.Vinayagamoorthy } \\
\text { P.V.Mohanraj }\end{array}$ \\
\hline Name of the villages & $\begin{array}{l}\text { Kullampalayam } \\
\text { Bommanaikan } \\
\text { palayam } \\
\text { Odathurai }\end{array}$ & $\begin{array}{l}\text { Kullampalayam } \\
\text { Bommanaikanpalayam } \\
\text { Ponnachi Pudur }\end{array}$ \\
\hline $\begin{array}{l}\text { Total rainfall during the cropping } \\
\text { period (mm) } \\
\text { Banana variety used }\end{array}$ & Kat5.5 & 968.3 \\
\hline
\end{tabular}

Table.2 Comparison of yield, water use and economics of Banana under drip fertigation (DF) and conventional method (Conv.)

\begin{tabular}{|c|c|c|c|c|c|c|}
\hline \multirow[t]{2}{*}{ Particular } & \multicolumn{2}{|c|}{2016} & \multicolumn{2}{|c|}{2017} & \multicolumn{2}{|c|}{ Mean } \\
\hline & DF & Conv. & DF & Conv. & DF & Conv. \\
\hline Yield $\left(\mathrm{t} \mathrm{ha}^{-1}\right)$ & 21.2 & 15.2 & 18.8 & 14.2 & 20.0 & 14.7 \\
\hline Percent yield increase & 28.3 & - & 24.5 & - & 26.4 & - \\
\hline Total water use (mm) & 1640 & 2100 & 1660 & 2067 & 1650 & 2084 \\
\hline $\begin{array}{l}\text { Percent water saving } \\
\text { by drip fertigation }\end{array}$ & 28.0 & - & 24.5 & & 26.3 & - \\
\hline $\begin{array}{l}\text { Water Use Efficiency } \\
\left(\mathrm{kg} \mathrm{hamm}^{-1}\right)\end{array}$ & 12.9 & 7.2 & 11.3 & 6.9 & 12.1 & 7.1 \\
\hline Cost of cultivation ( $\left.\mathrm{Rs} \mathrm{ha}^{-1}\right)$ & 152100 & 136917 & 150833 & 137917 & 151467 & 137417 \\
\hline Gross income $\left(\mathrm{Rs} \mathrm{ha}^{-1}\right)$ & 846667 & 606667 & 659167 & 495833 & 752917 & 551250 \\
\hline Net income (Rs ha $\left.{ }^{-1}\right)$ & 694567 & 469750 & 508333 & 357917 & 601450 & 413833 \\
\hline $\begin{array}{l}\text { Additional net income in DF } \\
\left(\mathrm{Rs} \mathrm{ha}^{-1}\right)\end{array}$ & 224817 & - & 150417 & - & 187617 & - \\
\hline B:C ratio & 5.57 & 4.44 & 4.37 & 3.60 & 4.97 & 4.02 \\
\hline
\end{tabular}

Thus it is evident that adoption of drip fertigation gained an additional mean net income of Rs 1,87,617 $\mathrm{ha}^{-1}$ than conventional method. The extra expenditure needed to meet the cost of drip fertigation over conventional method of banana cultivation was very well compensated by the enhanced yield. Basavarajappa et al., (2010) who found that the highest net returns and the benefit cost ratio were obtained in the drip irrigation treatment which received irrigation at $100 \%$ of crop ET and the lowest were obtained in the furrow irrigation treatment.

Shashidhara et al., (2007) found that drip irrigation had higher benefit cost ratio as compared to surface irrigation. Pramanik and Biswas (2012) observed that the drip fertigation system is more profitable as compared to surface irrigation (conventional method) due to increase in yield of banana plant. 
Pramanik et al., (2014) observed that the drip fertigation system was found more profitable compared to surface irrigation (conventional method) in ratoon crop also due to increase in banana yield.

The study clearly suggests the advantage of drip and fertigation with applying precise amounts of water and fertilizer nutrients over surface irrigation and conventional soil fertilization for banana production. It is concluded from the study that drip irrigation favourably influenced the banana yield which resulted in higher irrigation WUE against lower amounts of water applied. Apart from advantage of water saving over conventional irrigation, drip system proved to be very effective and efficient method of irrigation for cultivation of banana crop.

Moreover, benefit-cost ratios with different discount rates indicated that drip investment in banana cultivation is economically significant. The practice of drip irrigation should be encouraged in the banana fields. Since the farmers are getting water for the low cost from the public irrigation system, they are least interested to adopt this technology.

\section{Acknowledgement}

This research work was carried out under All India Coordinated Research Project on Irrigation Water Management, Bhavanisagar centre, Tamil Nadu.

\section{References}

Anonymous. National Horticulture Database, 2009.

Basavarajappa HB, Polisgowdar BS, Patil MG. Effectiveness and cost economics of fertigation in brinjal (Solanum melongena L.) under drip and furrow irrigation. Karnataka Journal of
Agricultural Science. 2010; 24(3):417419.

Hedge DM, Srinivas K. Growth, productivity and water use of banana under drip and basin irrigation in relation to evaporation replenishment. Indian $\mathbf{J}$. Agron.,1990; 35(1-2):106-112.

Kumar D, Pandey V. Effect of NPK fertigation on growth, yield and quality of banana 'Rasthali'

(AABPathkapoora) in coastal agroclimatic conditions of eastern India. Indian Journal of Agricultural Sciences. 2008; 78(9):798-800.

Narayanamoorthy A. Averting water crisis by drip method of irrigation: A study of two water intensive crops. Indian Journal of Agricultural Economics. 2003;58(3):427-437.

Narayanamoorthy A. Beneficial impact of drip irrigation. A study based on western India. Water Resource Journal. 1997; 195:17-25.

Pramanik S, Biswas RK. Effect of dripfertigation on soil moisture distribution and irrigation water use efficiency of banana in West Bengal.Journal of Soil and Water Conservation. 2012; 11(3):210-217.

Pramanik S, Patra SK. Growth, Yield, Quality and Irrigation Water Use Efficiency of Banana under Drip Irrigation and Fertigation in the Gangetic Plain of West Bengal. World Journal of Agricultural Sciences. 2016; 12(3):220228.

Pramanik S, Tripathi SK, Ray R, Banerjee H. Economic Evaluation of Dripfertigation System in Banana cv. Martaman (AAB, Silk) Cultivation in New Alluvium Zone of West Bengal. Agricultural Economics Research Review, 2014; 27:103-109

Raina JN, Sharma Tarika, Suman Shashi. Effect of drip fertigation with differentfertilizers on nutrient 
distribution in soil, leaf nutrient content and yield of apricot (Prunus aremeniaca L.). J Indian Soc. Soil Sci. 2011; 59:268-277.

Sharma R, Kispotta W. Study on Drip Irrigation in Banana - District of Kaushambi (U.P.).Journal of Business and Management (IOSR-JBM).2016; 18(1): $10-12$.

Shashidhara KK, Bheemappa A, Hirevenkanagoudar LV, Shashidhar
KC. Benefits and constraints in adoption of drip irrigation among the plantation crop growers. Karnataka J. Agril. Sci. 2007; 20:82-84.

Thadchayini T, Thiruchelvam S. An economic evaluation of a drip irrigation project for banana cultivation in Jaffna District. Water professional Day Symposium. Water resources research in Sir Lanka, 2005.

\section{How to cite this article:}

Bhuvaneswari. J., G. Thiyagarajan, M. Manikandan, S. K. Natarajan and Thenmozhi. S. 2020. Evaluation of Drip Fertigation in Banana in Kugulur Distributary of LBP Canal Command Area. Int.J.Curr.Microbiol.App.Sci. 9(06): 2423-2428.

doi: https://doi.org/10.20546/ijcmas.2020.906.297 